\title{
Lech Kurkliński
}

ALTERUM Ośrodek Badań i Analiz Finansowych; Warszawski Instytut Bankowości e-mail: lech.kurklinski@data.pl

\section{ZAGROŻENIA EGZYSTENCJALNE OBECNEGO MODELU POLSKIEJ BANKOWOŚCI SPÓLDZIELCZEJ EXISTENTIAL THREATS OF THE PRESENT MODEL OF POLISH COOPERATIVE BANKING}

DOI: 10.15611/pn.2018.531.26

JEL Classification: G21

Streszczenie: Artykuł poświęcony jest zagrożeniom rozwojowym sektora bankowości spółdzielczej w Polsce. W szczególności dotyczy niedostosowania banków spółdzielczych do nowych uwarunkowań rynkowych, technologicznych, regulacyjnych i demograficzno-kulturowych. Analiza dotychczasowego modelu organizacyjno-biznesowego pokazuje pojawienie się poważnych negatywnych zjawisk i zapowiedź ich eskalacji. Wskazane są konkretne obszary wymagające zmian. Brak podjęcia odpowiednich działań o charakterze integracyjnym i centralizacyjnym prowadzić będzie do wyeliminowania tego sektora z rynku.

Słowa kluczowe: bankowość spółdzielcza, model organizacyjno-biznesowy.

Summary: The article is devoted to the development threats of the cooperative banking sector in Poland. In particular, it concerns the maladjustment of cooperative banks to new market, technological, regulatory and demographic and cultural conditions. The analysis of the current organizational and business model shows the appearance of serious negative phenomena and the announcement of their escalation. Specific areas for change are indicated. The action should mainly concern the integration and centralization. The lack of action will lead to the elimination of this sector from the market.

Keywords: cooperative banking, organizational and business model.

\section{Wstęp}

Polska bankowość spółdzielcza weszła w okres szczególnie ważny dla jej egzystencji i rozwoju. Wyczerpują się możliwości utrzymania pozycji rynkowej wynikające z ekstensywnego charakteru jej modelu biznesowego. Nowe wyzwania wiążą się z czynnikami o charakterze technologicznym (rewolucja cyfrowa), regulacyjnym (obciążenia pokryzysowe), demograficzno-kulturowym (zacieranie się różnic pomię- 
dzy wsią i małymi miastami a dużymi aglomeracjami, zmiany pokoleniowe) oraz presją ze strony konkurentów (głównie banków komercyjnych). Wszystko to wymaga od banków spółdzielczych (BS) wdrożenia strategii dostosowanej do tych uwarunkowań.

Celem niniejszego artykułu jest przedstawienie obecnej sytuacji sektora bankowości spółdzielczej w Polsce, której analiza wskazuje na konieczność odejścia od dotychczas stosowanego modelu organizacyjno-biznesowego. Stawiana hipoteza mówi, że samodzielne (bez działań integracyjnych) funkcjonowanie banków spółdzielczych w tradycyjnej formule depozytowo-kredytowej, wobec dynamicznie zmieniających się uwarunkowań, stwarza zagrożenia dla egzystencji tego typu bankowości.

\section{Problemy dotychczasowego modelu bankowości spółdzielczej}

Przyszły rozwój, a nawet przetrwanie bankowości spółdzielczej w najbliższych latach będzie w dużej mierze zależeć od reform pozwalających na osiąganie odpowiedniej rentowności i efektywności. Dotychczasowe opieranie się głównie na marży odsetkowej w warunkach niskich stóp procentowych i narastającej konkurencji staje się nieskuteczne.

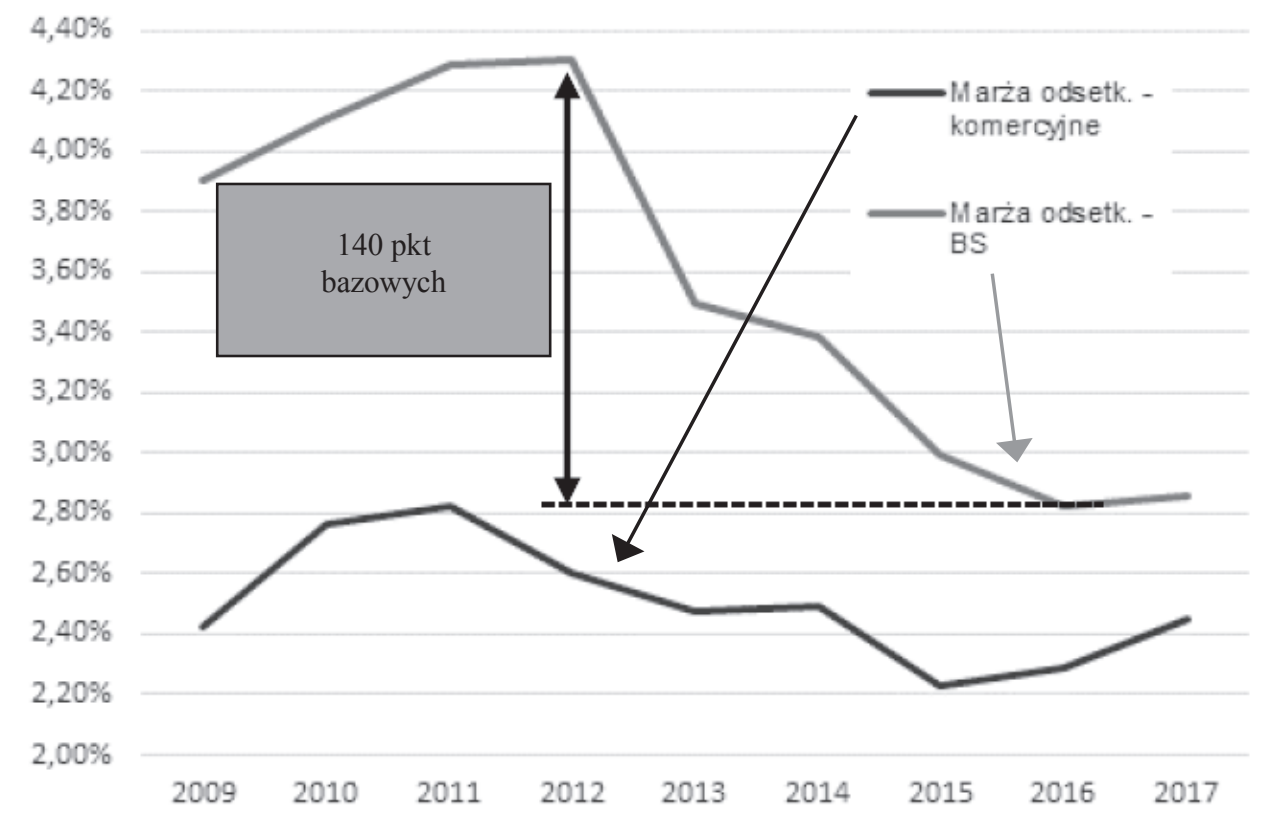

Rys. 1. Marża odsetkowa dla banków komercyjnych i BS-ów (w \%)

Źródło: [Banasiak 2018, s. 5]. 
Model polskiego BS-u jest stosunkowo prosty. Ma charakter depozytowo-kredytowy, o wybitnie odsetkowym charakterze tworzenia dochodów. Praktycznie wszyscy są uzależnieni od tego wzorca działania. Problemy z rentownością biorą się m.in. z nienadążania za czynnikami determinującymi efektywność bankowości komercyjnej. Na tę sytuację i jej dynamikę wpływ mają [Lepczyński 2017, s. 64]:

1) postępująca cyfryzacja kanałów dystrybucyjnych, z naciskiem na bankowość mobilną,

2) upraszczanie procesów kredytowych i automatyzacja badania wiarygodności kredytowej klientów, z wykorzystaniem wewnętrznych i zewnętrznych baz danych,

3) personalizacja relacji z klientem poprzez rozbudowę systemów informatycznych i wykorzystywanie metod określanych mianem BIG DATA,

4) racjonalizacja kosztów, wynikająca z automatyzacji procesów operacyjnych i szerokiego zastosowania outsourcingu.

Stan ten zaostrza silna konkurencja w ramach samego sektora BS-ów. Działając w ramach tradycyjnego modelu, możliwości poprawy wyników skupiają się na ekstensywnym rozwoju w formie rozszerzania aktywności stacjonarnych placówek. Przede wszystkim dotyczy to małych miejscowości, gdzie działają już inne BS-y. Rywalizacja wewnątrzsektorowa nasila się i ma charakter samowyniszczający się.

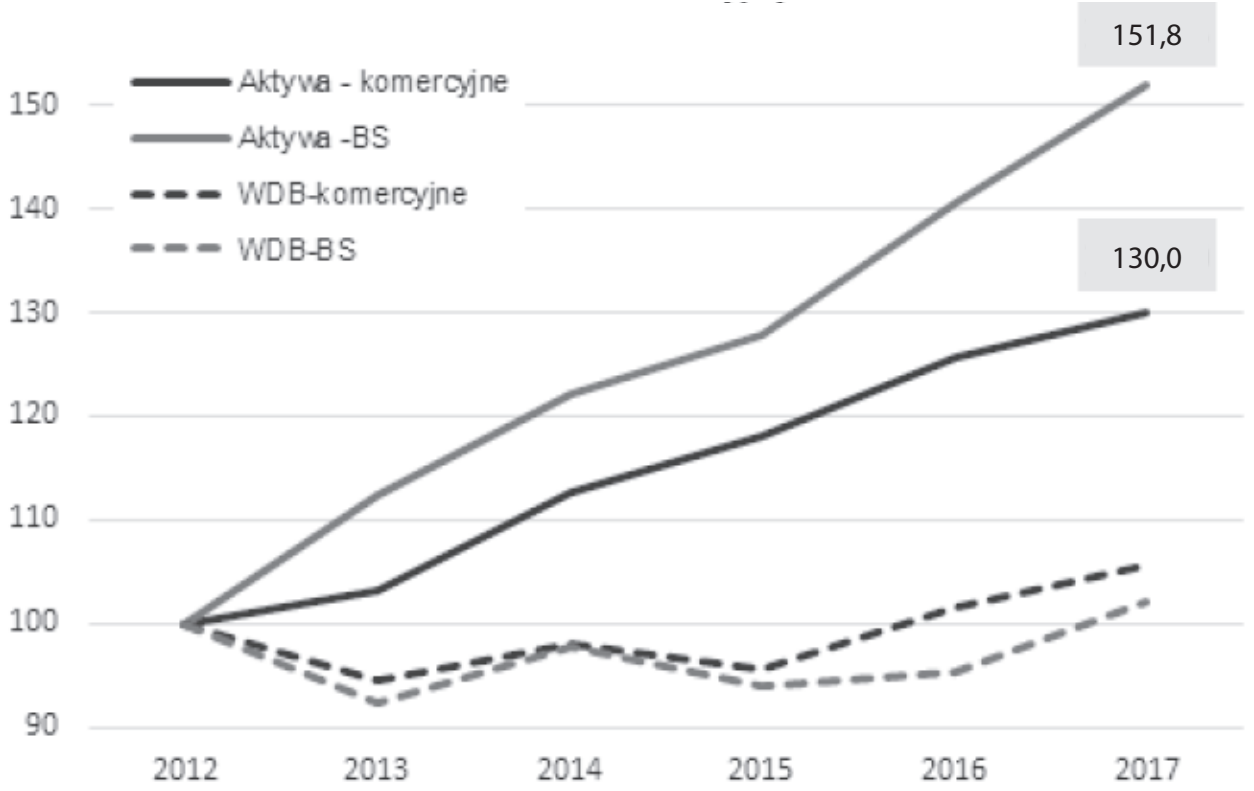

WDB - wynik na działalności bankowej; $2012=100 \%$

Rys. 2. Wzrost aktywów i dochodów w bankach komercyjnych i BS-ach (dynamika w \% w latach 2012-2017)

Źródło: [Banasiak 2018, s. 8]. 
Dodatkowo muszą one znacząco zwiększać swoje aktywa, aby zachować wyniki finansowe na dotychczasowym poziomie (wzrost aktywów o 51,8\% w okresie 5 lat przy praktycznie tym samym efekcie - patrz rys. 2). Podobne zjawisko zachodzi w bankach komercyjnych, ale w zdecydowanie mniejszej skali i przy obciążeniu podatkiem bankowym, którego nie płacą BS-y.

Banki spółdzielcze są zróżnicowanie wewnątrz własnej grupy. Można je podzielić na mniejsze, średnie i duże ${ }^{1}$. Ich strategie funkcjonowania różnią się. Część skupia się na lokalnym rynku i są to podmioty z pierwszej grupy. Występuje tu atut znajomości miejscowych uwarunkowań i klientów (czynnik relacyjności), co pozwala na zachowanie dobrej jakości portfela kredytowego, jednakże z reguły skromnego, a nadwyżki finansowe lokowane są w bankach zrzeszających. Jak dotychczas mała skala działalności zapewnia jeszcze zdolność do generowania skromnych zysków. Jednakże zarysowuje się problem zapewnienia dochodów pozwalających na pokrycie kosztów (dotyczy też nakładów inwestycyjnych) wynikających z nowych wymogów regulacyjnych, potrzeb technologicznych, dorównania rynkowi pracy itd. Praktycznie tego typu banki zorientowane są na przetrwanie, co na obecnym etapie jest jeszcze możliwe. Stąd też nie widać tu presji na zmianę modelu organizacyjno-biznesowego. Kolejna grupa to banki średnie. Część z nich radzi sobie w obecnych warunkach, podobnie jak małe podmioty. Natomiast część widzi konieczność ekspansji, która jednak przybiera charakter ekstensywny. Banki te powoli tracą swój walor relacyjności, co nierzadko odbija się na wynikach finansowych (zwłaszcza jakości portfela). W tym gronie najsilniej ujawnia się dostrzeżenie potrzeb zmian modelowych. Pozostają jeszcze banki duże. Charakter ich działalności zbliża się do modelu małego banku komercyjnego, obsługującego klientów detalicznych i MŚP. Mogą one wybrać drogę samodzielnego funkcjonowania poza zrzeszeniami (obecnie 2 banki) lub próbować się wpasować w struktury integracyjne (bank zrzeszający, IPS, zrzeszenie zintegrowane). W tym przypadku efekty są mocno zróżnicowane, począwszy od dobrych wyników BS w Brodnicy (ROE za 2016 r. - 8,53\% [BS w Brodnicy 2017, s. 19], akceptowalnych Krakowskiego Banku Spółdzielczego (ROE za 2016 r. - 3,22\% [KBS 2017, s. 8]), do bankructwa SK Banku czy problemów Podkarpackiego Banku Spółdzielczego (program naprawczy). Przede wszystkim należy sobie zadać pytanie, czy jest przyszłość dla względnie małego banku o charakterze uniwersalnym, nawet dobrze zarządzanego, ale jedynie z przewagą konkurencyjną w postaci znajomości rynku regionalnego i ewentualnej większej elastyczności w podejmowaniu decyzji?

Problemy samych BS-ów to niejedyne obszary nieefektywności i zagrożeń dla tego sektora. Nie mniej ważnym wyzwaniem jest również model działalności banków zrzeszających i ich relacje $\mathrm{z}$ bankami zrzeszonymi. W praktyce dotychczas banki zrzeszające:

1 Z reguły przyjmuje się kryterium wielkości sumy bilansowej do kategoryzacji banków spółdzielczych: małe do $200 \mathrm{mln}$ zł, średnie od 200 do $500 \mathrm{mln}$ zł i duże od $500 \mathrm{mln}$ zł [NBP 2017, s. 39]. 
1) nierzadko konkurowały z BS-ami, co uniemożliwiało przyjęcie roli faktycznego lidera zrzeszenia,

2) słabo koordynowały działalność grupy i nie zapewniały jej bezpieczeństwa biznesowego (własne trudności - konieczność prowadzenia programów naprawczych),

3) w sposób patologiczny tworzyły konsorcja kredytowe z BS-ami lub dokonywały obrotu wierzytelnościami,

4) nieefektywnie inwestowały środki lokowane w nich przez zrzeszone banki,

5) wykazywały się słabością w budowaniu siły technologicznej zrzeszeń, chociaż Bank SGB SA wdrożył zintegrowany system IT, ale mimo upływu kilku lat przystąpiło do niego tylko kilkanaście podmiotów.

Przy analizie modelu organizacyjno-biznesowego sektora BS-ów nie można pominąć kwestii systemów ochrony instytucjonalnej IPS. Niewątpliwie wzmacniają one bezpieczeństwo zrzeszonych banków. Są ważnym filarem w tej sferze, niemniej zbierają dopiero doświadczenie, ale przede wszystkim nie wyręczą banków zrzeszających, co pokazują doświadczenia z innych krajów [Lepczyński 2017, s. 23 i 59].

Niezmiernie istotnym problemem w polskim sektorze bankowości spółdzielczej jest kurczenie się bazy członkowskiej. To zjawisko może okazać się szczególnie niebezpieczne dla przyszłej pozycji BS-ów, gdyż to członkowie budują siłę i tożsamość tych instytucji. Pojawił się jeszcze czynnik związany z upadłościami spółdzielczych banków i kas oszczędnościowo-kredytowych. Obciążają one wizerunek całego sektora i stanowią potencjalne zagrożenie o charakterze reputacyjnym, zwłaszcza patrząc przez pryzmat jednostek samorządu terytorialnego nieobjętych gwarancjami depozytów.

\section{Oceny dominującego modelu bankowości spółdzielczej}

W świetle wcześniejszych uwag nasuwa się kolejne pytanie dotyczące samooceny spółdzielców. W tym celu przeprowadzono ankiety w 2013 r. i 2016 r. ${ }^{2}$ Wyniki pierwszej wskazywały na korzystną ocenę sytuacji, gdyż tylko $15 \%$ banków widziało potrzebę dokonania pilnych zmian w sektorze, a prawie $50 \%$ uznało ją za stabilną, nawet $\mathrm{w}$ długim horyzoncie. Jednakże po trzech latach proporcje odwróciły się i 76\% respondentów uważało ich model za niestabilny, chociaż główną przyczynę upatrywano w kwestiach regulacyjnych. W tych warunkach tylko niecała połowa (48\%) banków rozumie potrzebę reform, natomiast pozostała część $(52 \%)$ chciałaby pozostawienia wszystkiego bez zmian [Kil 2018, s. 221-225].

Powyższe spostrzeżenia zmuszają do refleksji, że samo środowisko BS-ów jeszcze słabo odczuwa zagrożenia. Dominuje poczucie wiary w dotychczasowe wartości wnoszone przez bankowość spółdzielczą, takie jak znajomość lokalnego rynku,

2 Badania zostały przeprowadzone przez K. Kila i E. Miklaszewską z Uniwersytetu Ekonomicznego w Krakowie przy wsparciu Banku Polskiej Spółdzielczości SA na grupie odpowiednio 66 w 2013 r. i 60 banków spółdzielczych w 2016 r. (wśród kadry kierowniczej) [Kil 2018, s. 199]. 
elastyczność działania i relacyjność. Jednakże cechy te są przynależne podmiotom lokalnym. Niestety duża część BS-ów w Polsce traci ten walor. Wychodzenie na inne rynki stanowi wyzwanie wiążące się z obsługą nieznanych klientów, w nowych środowiskach. W wielu przypadkach są z tym problemy, gdyż BS-y nie potrafią profesjonalnie zarządzać ryzykiem kredytowym, wykorzystując najnowsze metody (wsparcie technologiczne, korzystanie z odpowiednich baz danych, automatyzacja procesów itd.). Ponadto rozszerzanie zakresu geograficznego aktywności najczęściej oznacza utratę relacyjności. W efekcie wzrasta poziom kredytów zagrożonych (I półrocze 2017 r.: 7,1\% dla BS-ów i 15,9\% dla banków zrzeszających), który przekroczył wskaźniki dla całego sektora bankowego (5,9\%), a jeszcze do niedawna sytuacja była odwrotna [UKNF 2017, s. 13].

Powyższe dane są jeszcze bardziej niepokojące, gdy spojrzymy na rezerwy celowe na kredyty zagrożone. Relacja odpisów do należności ze stwierdzoną utratą wartości wynosiła w $2017 \mathrm{r}$. w bankach komercyjnych 56,3\%, zatem prawie dwukrotnie więcej niż w sektorze spółdzielczym (30\%). Utworzenie rezerw w analogicznej wysokości kosztowałoby dodatkowo BS-y 1,2 mld zł, czyli równowartość 2-krotnego zysku za 2016 r. [UKNF 2017, s. 14]. Straty kredytowe należą do czynników najmocniej różnicujących sytuację finansową i w największym stopniu przyczyniały się do odnotowanych upadłości lub wymuszonych fuzji.

Od strony kosztów operacyjnych i nakładów inwestycyjnych także powstała znacząca luka pomiędzy bankami komercyjnymi a spółdzielczymi. Osiągają one zdecydowanie niższy wynik na działalności bankowej, który zmusza do ograniczania kosztów bieżących (rzeczowych i osobowych). Poziom zatrudnienia w BS-ach generuje relatywnie wysoki fundusz płac, którego racjonalizacja następuje poprzez niższe wynagrodzenia, co zmniejsza atrakcyjność zatrudnienia [Zygierewicz 2018].

\section{Uwarunkowania rozwojowe bankowości spółdzielczej}

Uwarunkowania, w jakich rozwija się współczesna bankowość spółdzielcza w Polsce, można rozpatrywać według różnych przekrojów i kryteriów. Jednakże do najważniejszych należałoby zaliczyć te o charakterze:

1) rynkowym,

2) regulacyjnym,

3) technologicznym

4) demograficzno-kulturowym.

Jeśli chodzi o rynek, to wymieniane już były czynniki związane ze środowiskiem niskich stóp procentowych. Obniża się marża uzyskiwana przez banki, a jest to dla bankowości spółdzielczej główne źródło dochodów. Sytuacja ta powinna zmuszać do poszukiwania innych sposobów zarabiania (dochody pozaodsetkowe). W tej sferze BS-y radzą sobie bardzo słabo. Ratuje je zdolność do akwirowania względnie tanich depozytów i oczekiwanie atrakcyjniejszych warunków lokowania nadwyżek w bankach zrzeszających. Presja ta prowadzi do trudności w zarządza- 
niu aktywami i pasywami w zrzeszeniach. Jakość ich portfela kredytowego jest tu bardzo wymownym wskaźnikiem. Stan ten powoduje trudności finansowe, których mechanizm powstawania pokazuje rys. 1 .

\section{Tradycyjny model depozytowo-kredytowy BS-ów nacisk na dochody odsetkowe}

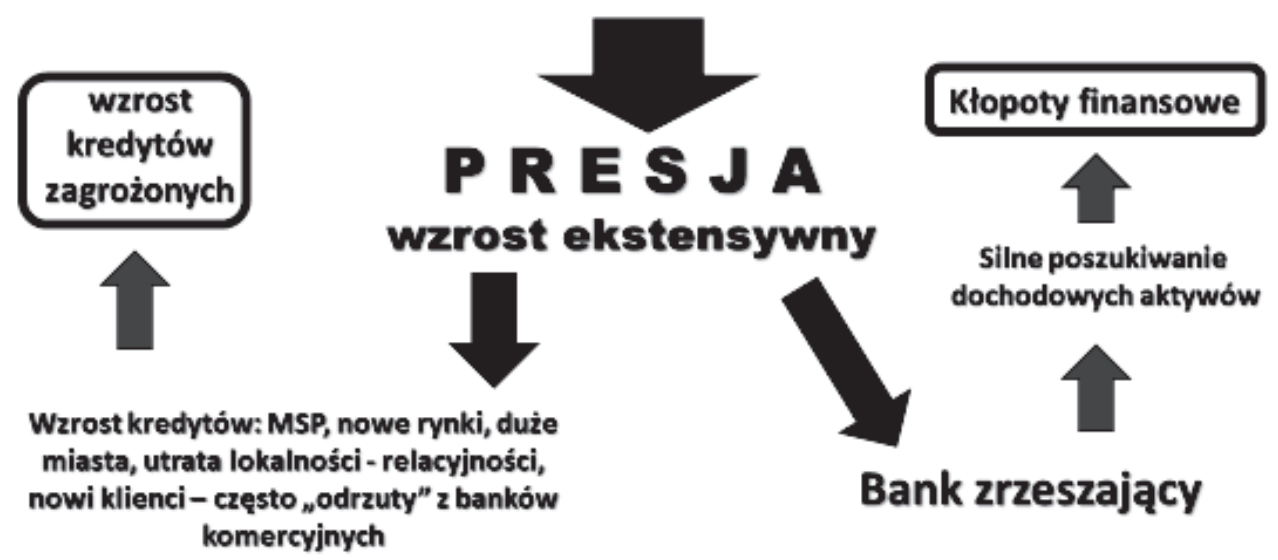

Rys. 3. Mechanizm presji BS-ów na wynik odsetkowy

Źródło: opracowanie własne.

Uwarunkowania regulacyjne należą do głównych współczesnych determinant rozwoju sektora bankowego. W szczególności dotyczy to bankowości spółdzielczej, gdyż ogrom regulacji, jakie spadły na banki po ostatnim kryzysie finansowym, najbardziej odczuły małe instytucje. Choć BS-y nie przyczyniły się do jego powstania, przeszły ten okres całkiem nieźle, to regulatorzy postanowili nałożyć nowe wymogi ostrożnościowe praktycznie na wszystkie banki, tylko w bardzo niewielkim stopniu stosując zasadę proporcjonalności. Małe podmioty obciążone zostały niewspółmiernymi do ich skali kosztami i obowiązkami. Wbrew pierwotnym intencjom legislatorów to duże banki uzyskały dzięki temu przewagi konkurencyjne, gdyż obciążenia regulacyjne okazały się dla nich relatywnie mniejsze.

Postępująca cyfryzacja gospodarki i życia społeczeństwa ma daleko idące konsekwencje dla współczesnych i przyszłych modeli biznesowych banków. Jak do tej pory główna ostoja pozycji spółdzielczości opiera się na stacjonarnej, tradycyjnej sieci placówek. Ta sytuacja występuje w całej Europie, jednakże w Polsce ma ona zdecydowanie większe znaczenie. Europejska bankowość spółdzielcza posiada ok. 20-procentowy udział w rynku, a dysponuje ok. 30\% sieci oddziałów. Natomiast w naszym kraju udział rynkowy banków spółdzielczych nie przekracza 10\%, jed- 
nakże mają one ok. 40\% placówek. Dysproporcja ta wynosi zatem 1:4, a w Europie tylko 1:1,5 [Groeneveld 2017, s. 16-20]. Posiadanie tak dużej sieci oddziałowej istotnie rzutuje na ponoszone koszty.

Znaczenie bankowości elektronicznej jeszcze się wzmocni po wdrożeniu dyrektywy PSD 2. Banki zostaną zmuszone do otwarcia dostępu do kont poprzez tzw. trzecich dostawców. Najczęściej wymienia się tu firmy fintech, ale równie dobrze mogą to być inne banki (np. komercyjne), mocniej zaawansowane technologicznie. Powstaje ogromne ryzyko utraty klientów albo części ich aktywności (tej najbardziej dochodowej). Słabsze pod tym kątem BS-y mogą stać się stosunkowo łatwym celem, co jest już tematem dyskusji w środowisku bankowym. Podobny komentarz może też dotyczyć cyberzagrożeń.

Cyfryzacja oznacza też ułatwienia i optymalizację procesów operacyjnych i biznesowych. Można wymienić chociażby dziedzinę BIG DATA czy sztuczną inteligencję, ale racjonalne korzystanie $\mathrm{z}$ tych rozwiązań wiąże się z efektem skali, który trudno jest uzyskać w małym BS-ie. Rewolucja technologiczna wkracza we wszystkie obszary (płatności, ocena zdolności kredytowej, kanały komunikacji, akwizycja, segmentowanie klientów, bezpieczeństwo itd.).

Należy dodać przemiany o charakterze demograficznym i cywilizacyjno-kulturowym. Dla młodego pokolenia wizyty w oddziałach stają się zbędne, tym bardziej że dostępność nowoczesnych rozwiązań technologicznych upowszechnia się także na wsi i w małych miastach. Słabnie czynnik tradycji i pokoleniowej lojalności wobec dostawców różnego typu usług, w tym finansowych. Zmiany te uderzają w tradycyjny model bankowości spółdzielczej.

\section{Propozycje integracji modelu bankowości spółdzielczej}

Dla zewnętrznego obserwatora wydaje się niezbędne podjęcie wysiłków reorganizacyjnych. Posiłkować się można doświadczeniami z innych krajów, np. z Niemiec czy Finlandii, gdzie sektory spółdzielcze bardzo dobrze konkurują z bankowością komercyjną [Kurkliński, Miklaszewska (red.) 2017; Ayadi i in. 2010]. Dla zwiększenia zyskowności i budowy odpowiedniej bazy kapitałowej banków spółdzielczych za priorytetowe można uznać trzy główne kierunki działań:

1) stabilny wzrost zdywersyfikowanych dochodów,

2) poprawa zarządzania ryzykiem, zwłaszcza kredytowym,

3) optymalizacja kosztów funkcjonowania.

Praktycznie każdy z wymienionych obszarów wymaga co najmniej częściowej centralizacji funkcjonowania banków spółdzielczych. Dla rozszerzenia i skuteczności oferty produktowej niezbędne jest współdziałanie (efekt skali), np. w zakresie:

a) kredytu konsumenckiego, kart kredytowych,

b) bancassurance,

c) rozliczenia w handlu zagranicznym,

d) leasingu, faktoringu, 
e) współpracy np. z fintechami.

W sferze zarządzania ryzykiem, w tym zwłaszcza kredytowym, nie wystarcza już tylko znajomość lokalnego rynku, szczególnie przy rozszerzaniu geograficznej aktywności. Niezbędny jest tu profesjonalizm (wspomagany technologicznie) również trudny do osiągnięcia na szczeblu małego podmiotu. Dodatkowo należy tu uwypuklić problemy kadrowe banków spółdzielczych, zwłaszcza w odniesieniu do specjalistów. Praca w BS-ie staje się coraz mniej atrakcyjna. Dotyczy to zarówno poziomu płacowego, jak i możliwości rozwoju zawodowego. Już pojawiają się trudności w znalezieniu osób o odpowiednich kwalifikacjach w małych miejscowościach (m.in. informatyków, specjalistów od audytu i compliance, ekspertów do spraw ryzyka).

Wymogiem koniecznym staje się optymalizacja kosztów funkcjonowania, której nie osiągnie się bez centralizacji. Nie przesądzając o finalnej postaci, w jakiej mogłaby nastąpić integracja i uwspólnienie funkcji całego sektora, można wskazać na te o charakterze wewnętrznym i zewnętrznym. Do pierwszej grupy należałoby zaliczyć:

a) utrzymanie i rozwój głównych systemów informatycznych,

b) infrastrukturę i bezpieczeństwo teleinformatyczne, help desk,

c) IT dla produktów i dokumentację produktową,

d) obsługę bankomatów i kart płatniczych,

e) sprawozdawczość obowiązkową, finansową i zarządczą,

f) windykację,

g) centralne zakupy,

h) korespondencję.

Katalog ten jest otwarty i może ulegać zmianom. W skład funkcji zewnętrznych w modelu zintegrowanym wchodzą:

a) zagospodarowanie nadwyżek finansowych (alokacja aktywów),

b) prowadzenie rozliczeń,

c) konsorcja kredytowe, wsparcie obsługi „rosnących” klientów,

d) relacje z dużymi partnerami (np. sieci handlowe) i instytucjami państwowymi,

e) aktywność międzynarodowa,

f) sprawozdawczość zrzeszeniowa.

Proponowane zmiany w pewnym stopniu osłabią główne atuty bankowości spółdzielczej (elastyczność, relacyjność). Jednakże nie powinno to nastąpić w dużym stopniu, doprowadzającym do utraty tych przewag konkurencyjnych. O możliwości ich utrzymania świadczą doświadczenia i bardzo dobre wyniki uzyskiwane przez bankowość spółdzielczą w innych krajach.

\section{Zakończenie}

Model zintegrowany funkcjonuje za granicą (aczkolwiek w wybranych państwach), gdzie udało się zbudować i utrzymać wysoko rozwinięte i efektywne systemy ban- 
kowości spółdzielczej. Pozostaje zatem określenie, jaką rolę winny pełnić w Polsce same banki. Do naśladowania można przyjąć rozwiązania niemieckie lub fińskie. Tam banki są samodzielnymi podmiotami, autonomicznie podejmującymi decyzje. W pełni odpowiadają za ryzyko prowadzonej działalności i jej wynik finansowy. Podejmują decyzje co do ostatecznego kształtu oferty handlowej. Jednakże najczęściej uczestniczą we wspólnych kampaniach marketingowych pod egidą zrzeszeń zakładających jednolite parametry oferowanych produktów. Dla banku spółdzielczego zostają zarezerwowane relacje w lokalnym środowisku, inicjatywy społeczne i decyzje sponsorskie. Natomiast przede wszystkim korzystają z usług wspólnych, zarówno wewnętrznych, jak i zewnętrznych, w celu optymalizacji własnego wyniku finansowego oraz obniżenia ryzyka prowadzonej działalności. W Polsce nie ma przeszkód formalnych, aby ten model został przyjęty. Największą barierą pozostaje mentalność i stanowisko kadr kierowniczych większości BS-ów. Brak podjęcia stosownych działań integracyjnych może prowadzić do zagrożenia egzystencjalnego całego sektora bankowości spółdzielczej w Polsce, którego pierwsze symptomy już się pojawiły.

\section{Literatura}

Ayadi R., Llewellyn D.T., Schmidt R.H., Arbak E., De Groen W.P., 2010, Investigating Diversity in the Banking Sector in Europe: Key Developments, Performance and Role of Cooperative Banks, Brussels, CEPR.

Banasiak A., 2018, Sektor bankowy w Polsce. Uwarunkowania rozwoju, ZBP, Warszawa.

BS w Brodnicy, 2017, Zbiór informacji podlegajacych publikacji $w$ ramach polityki informacyjnej banku za rok 2016, Brodnica.

Groeneveld H., 2017, Snapshot of European Co-operative Banking 2017, EACB, Brussels.

KBS, 2017, Raportz badania sprawozdania finansowego Krakowskiego Banku Spótdzielczego za 2016 r., Kraków.

Kil K., 2018, Stabilność finansowa banków spółdzielczych w Polsce w świetle pokryzysowych zmian regulacyjnych, Wydawnictwo Poltext, Warszawa.

Kurkliński L., Miklaszewska E. (red.), 2017, Modele bankowości spółdzielczej na rynku europejskim i ich ewolucja w okresie pokryzysowym. Wnioski dla Polski, ALTERUM, Warszawa.

Lepczyński B., 2017, Model biznesowy bankowości spółdzielczej wobec wyzwań rynkowych i regulacyjnych, ALTERUM, Warszawa.

NBP, 2017, Raport o stabilności systemu finansowego, Warszawa.

UKNF, 2017, Informacja o sytuacji banków spółdzielczych i zrzeszajacych w I pótroczu 2017 r., Warszawa.

Zygierewicz M., 2018, Kadry polskiej bankowości spółdzielczej, „Nowoczesny Bank Spółdzielczy”, marzec. 